\title{
The Right to the City and the public sphere: between political participation and the renewal of the legal urbanistic order
}

\author{
Direito à Cidade e esfera pública: \\ entre a participação política e a renovação jurídico-urbanística
}

Arthur Hirata Prist [I] Maria Paula Dallari Bucci [II]

\begin{abstract}
This article proposes an analysis of the political and legal aspects of the Right to the City from the perspective of the concept of public sphere. The Right to the City is interpreted as a dynamic link between political mobilization, democratization of social relations and the State's institutional apparatus, and the guarantee of better conditions of existence in urban space. Based on bibliographical research about the urban social struggles in Brazil and in the city of São Paulo, the article intends to demonstrate that the Right to the City is exercised by the population through clashes in the public sphere responsible for stimulating the renewal of the legal order and for attributing new meanings to the existing Law.
\end{abstract}

Keywords: right to the city; public sphere; political participation; social function of property and city; social movements.

\section{Resumo}

0 artigo propõe uma análise dos aspectos políticos e jurídicos do Direito à Cidade sob a perspectiva do conceito de esfera pública. O Direito à Cidade é interpretado como um elo dinâmico entre a mobilização política, a democratização das relações sociais e do aparato institucional do Estado e a garantia de melhores condições materiais de existência no espaço urbano. A partir da revisão bibliográfica sobre o tema das lutas sociais urbanas no Brasil e na cidade de São Paulo, pretende-se demonstrar que o Direito à Cidade é exercido pela população a partir dos embates na esfera pública responsáveis por impulsionar a renovação da ordem jurídica e atribuir novos sentidos ao Direito existente.

Palavras-chave: direito à cidade; esfera pública; participação política; função social da propriedade e da cidade; movimentos sociais. 


\section{Introduction}

The plurality of appropriations of the concept of Right to the City made throughout history, since its initial formulation by Lefebvre (2008) in 1968, makes the task of delimiting a single definition of the concept quite complex and somewhat unreasonable. The fact is that the Right to the City presents itself as a common denominator in social struggles (Tavolari, 2016), encompassing both a critique of the reification of everyday life due to the submission of space and urban experience to the commercial logic and exchange value, as well as localized demands for access to minimum conditions for participation in the resources that the city provides.

To conceive the Right to the City in its polysemy also requires understanding that the concept cannot be reduced to a legal category in the way it is traditionally thought of. In spite of that, it's clear that the emergence of the concept and its multiple appropriations by academia and the social movements have been fundamental for promoting profound transformations in the legal consciousness based on critical thought on the role of law in the urbanization process.

In this sense, Fernandes (2005) defends overcoming the hegemonic urban-legal paradigm according to which urban space is conceived from the perspective of the private lot and the right to individual property. This conceptual paradigm is progressively confronted by another one, according to which the urban legal order must be established on the basis of two fundamental principles: the socio-environmental function of property and city and the democratic management of the city. A careful analysis of each of these principles, and especially of the interaction between the two, can contribute to a proper legal understanding of the Right to the City.

The principle of the social function of property and city relates, roughly speaking to, the functioning of urban land in the sense that it serves everyone equally (Alfonsin et al, 2017, p. 1225), and is, therefore, associated with a kind of urban space development that aims to meet collective and individual demands in an equal manner. Property regulation is thus removed from the private and individualistic realm to become a matter of public law through a collective dimension. The city, in turn, is no longer seen as the sum of individual properties, but as an organic and complex whole and as the fruit of collective work (Fernandes, 2005).

It can be said that the principle of the social function of property and city is associated with a material dimension of the Right to the City. It, therefore, concerns the regulation of the socioeconomic relations that shape the production of urban space and the guarantee of fundamental rights related to the enjoyment of the city. However, this principle has no predetermined content or application, which are historically produced by public deliberation, that is absorbed and interpreted by legal institutions. In this sense, this principle configures the incorporation of a political conflict by law (Haddad, 2019, p. 227). This observation already points to its interconnection with the principle of democratic management of the city.

The principle of democratic management of the city, in turn, is associated with a political dimension of the Right to the City. This dimension was explored by Gomes 
(2018) and can be defined as the right of the population to participate in the elaboration and implementation of urban policies, which requires the existence of participative channels (not necessarily institutional) that make it possible to understand the rights and interests that are demanded in social struggles. This political dimension was also explored by Harvey (2014), who defines the Right to the City as the collective power to manipulate and coordinate the process of urbanization. According to the author, the guarantee of the Right to the City is directly linked to the exercise of popular sovereignty over State activity, as well as to the democratic control over the production and use of the surplus capital in the process of urbanization (idem, pp. 61-2).

The differentiation between these two dimensions of the Right to the City, represented by the aforementioned legal principles, should not point to anything other than a constitutive interconnection between them, within which the possibility of social participation in the formulation of urban policy contributes directly to the application of the social function of property and city, and vice versa. As already pointed out, the principle of the social function of property and city has its content and conditions of application defined mainly by the interaction between the State and society, that is, by political participation.

In this article, it is assumed that the Right to the City cannot be reduced to a static legal definition, and that it exists solely in the field of interaction between its political dimension and its material dimension, exemplified in this article by the principles of the democratic management of the city and of the social function of property and city. Its realization as a right per se would therefore be verified when society's political participation results in the renewal of legal institutions in sense of functioning and democratization of urban land. In other words, the Right to the City is conceived as a dynamic link of reciprocal influence between political mobilization, the democratization of social relations and of the institutional apparatus of the State, and the guarantee of better conditions of existence in urban space. This article follows this analytical direction. Exploring this hypothesis requires, above all, an adequate understanding of how the interaction between State and society effectively takes place, which is why it will be given a central place to the concept of Public Sphere. Based on this theoretical reference, the research will be made in two stages: analysis of the social struggles for Urban Reform after the democratization of the Brazilian State, followed by a study focused on the city of São Paulo in its current context. The aim is to demonstrate that the guarantee of the Right to the City depends on society's political participation, and, consequently, the construction of a democratic public sphere.

\section{Public sphere and public interest}

The concept of public sphere ${ }^{2}$ refers to the spontaneous communicative flows that exist in society regarding issues of common and public interest, through which content, opinions, values and worldviews are shared, affecting the decision making, the formation of will and the construction of identity at 
individual and collective levels. The public sphere is thought of as the social space where discourses are externalized and deliberations are held by communities interested in a given matter of public interest, ultimately aiming to attain public consent and the rational and argumentative treatment of the diverse social matters (Habermas, 1997; Avritzer \& Costa, 2004; Melo, 2015).

Understood as an mediation instance between State and society, the public sphere is described as a "resonance box", where issues and questions arising from civil society, when addressed with appropriate intensity, signal to the State the need for public intervention. It is also thought of as a space legitimizing State activity in general (Machado et al., 2010). To better explain this interaction, one can use the differentiation between the "formal" public spheres - institutionalized spaces of deliberation and decision-making, internal to the State and the "informal" public spheres - spaces of communication located within civil society.

The formal public spheres constitute the "center" of the State's communication and decision-making system, which is composed of the institutional complex of the administration, the courts of justice and the state deliberative bodies such as the legislative power (Habermas, 1997, pp. 86-87). The decision-making of these bodies should be preceded by an open, inclusive, and informed deliberation, which should serve as context for legitimizing the decision made or the public policy to be implemented. Procedures and strategies for participation, dialogue, negotiation and harmonizing interests thus become fundamental for achieving consensus among the social groups involved in the public matter at stake, which often hold distinct and antagonistic interests. It is the function of Law to institutionalize procedures capable of providing equal representation for the multiple groups concerned by each matter under deliberation, granting democratic legitimacy to the decisionmaking process (Habermas, 1997, p. 105).

The informal public spheres, understood as the networks of informal communication internal to civil society that contributes to forming opinion and will, constitutes the periphery of the system. This instance is characterized by the activity of civil society associations, trade unions, social movements, cultural and religious institutions, the media, etc. (Habermas, 1997, pp. 87-88). Presented as spontaneous, differentiated flows, and characterized by the most diverse forms of protest and enunciation, the informal public sphere's own communicative actions do not necessarily seek reaching consensuses between distinct social groups, but mainly the continuous and exhaustive debate on issues of public interest from different points of view.

The informal public sphere is characterized by the political dissent, namely the confrontation between different subjective views, which contributes to the reformulation of values and practices and the occurrence of important paradigm shifts within the historical process. In the informal public sphere, social groups compete for influence, with the objective of obtaining public assent and therefore a context of "resonance" for their opinions, convictions, and political projects (Habermas, 1997, pp. 95-96).

The democratization of the State is associated with the more or less decisive role of the peripheral and informal communication processes in the development, the activity and the decision-making of the political system. 
This points to a necessary porosity of the State to the interests and demands externalized by social groups in their communicative and political interactions within the informal public sphere (Habermas, 1997, pp. 88-89). In other words, the binding decision taken by the State depends on a legitimation that can only emerge from an alignment with the expectations and needs of the population which are not given a priori, but formulated collectively through informal communication and political mobilization, and are therefore constantly changing.

This circulation of power from the periphery towards the center of the political system, however, is not the rule in most, if not all, of the contemporary democratic states, whose power is strongly centralized and exercised in an apparently autonomous manner, when not in the interests of a restricted minority with economic power. It has, however, been verified over the course of history that in certain circumstances the mobilization of the public sphere by subjects from civil society managed to reverse the official circulation of power, so that contributions coming from these subjects have been incorporated by the political system and the legal order. This depends on the ability of civil society groups to detect and interpret social problems, acting collectively to the point of influencing public opinion and, consequently, pressuring the State to articulate a certain form of public intervention or to promote a renewal of the legal order (Habermas, 1997, pp. 90-91).

It is, however, important to bear in mind that not every contribution or demand articulated by civil society necessarily represents a step towards the democratization of social relations. That is because a given "public opinion" on an issue, represents in the vast majority of cases only a partial consensus in relation to society as a whole, therefore originated from a localized context or from a particular set of subjects holding specific interests. The partiality of a public opinion by itself does not remove its legitimacy, given the extremely complex and heterogeneous context of contemporary societies. However, such an observation should alert us to the fact that, in certain cases, behind a supposed unanimity there may be a process of subordination or suppression of divergent opinions, resulting from the asymmetries of power existing in the social milieu.

The legitimacy of the influence that certain public opinion will exert on the State's activity is therefore associated with the degree of inclusion in the public debate that preceded it, which ideally should involve all potentially affected by the issue under deliberation (Habermas, 1997, pp. 92-98). Public opinions coming from exclusionary, restricted, or nonexisting spaces of deliberation would therefore have less legitimacy in influencing the decisionmaking within the State.

The "unfeasibility of the public sphere" pointed out by Arantes (2007, p. 21) would correspond to its treatment as "something private and personal" (Maricato, 2015a, p. 78), characteristic of patrimonial and elitist societies, where the interests of a minority are traditionally taken as representative of society as a whole. Consequently, the interests and needs of the majority of the population - lacking equal conditions of political representation and enunciation - 
are categorically neglected. Thus, it becomes central in every practical situation to know who can really participate in the porous formation of public opinion (Melo, 2015, p. 18).

This is a crucial task given that the public sphere, in the most diverse contexts, has been built based on constitutive exclusion, i.e. a selectivity in relation to the subjects capable of participating and making themselves heard in the social context and the content and opinions to be treated as "issues of public interest" (Fraser, 1992; Perlatto, 2015). The existence of a single and homogeneous public sphere is therefore not conceivable. We instead acknowledge a complex interaction between a multiplicity of "public", composed of diverse social subjects and varied forms of organization, solidarity, and enunciation (Avritzer \& Costa, 2004).

In summary, one can conceive, on one hand, the existence of a group of "public" articulated around a dominant public sphere, composed of the main hegemonic actors endowed with social and economic power, along with the mass media, and, on the other hand, a plurality of subaltern counter public, social spaces and discursive arenas where different disadvantaged groups establish their own world views, elaborate their identities and formulate their needs and demands. These public spheres relate to each other in a complex manner, being porous and complementary, although different from each other. From the interaction, often conflicting and dissenting, between dominant and subordinate "public", hegemonic discourses are countered by protests and counterdiscourses from communities traditionally excluded from the traditional spaces of deliberation and enunciation.
By denouncing the constitutive exclusions of the dominant public sphere, marginalized groups bring attention to the contradictions of a social structure that unequally distributes the capacity to be heard and to occupy the best places, to define objects of discussion and to deliberate on these (Pallamin, 2015, p. 23). By seeking conditions for "equal participation in common life", these collectives contribute to the constant redefinition of the sense of moral well-being and the outlines of what is public (ibid., p. 87). With this in mind, the public sphere must be understood as an entity in constant reconstruction, characterized by conflicting values and interests that are strongly antagonistic and in certain cases irreconcilable, which are the subject of continuous deliberations with progress in practical negotiations between different social groups in mind (Melo, 2015, p. 22).

It is in the multiple instances that make up the public sphere that such complex arrangements of dialogue, negotiation, contestation and protest are articulated, overlapping and interspersing themselves according to the practical situations, the objectives of the deliberation itself, the groups concerned and the interests at stake. As a result, the conditions for the legitimacy of the State's activity are reformulated and renewal processes of the legal order are stimulated. This perspective supports the concept of the Democratic State of Law as an unfinished project, and therefore fallible and in need of constant revision, as well as progressively reformulated by political participation, through which the system of rights and legal consciousness are updated, reinterpreted and institutionalized in a more appropriate manner (Habermas, 1997, p. 118). 
Currently, this impulse for renewal of the legal order and updating the State of Law particularly depends on the social, economic and cultural integration of the vulnerable and historically oppressed groups and on their greater participation in the deliberative processes of shaping public opinion and decision-making within the State. Specifically regarding the urban dimension of the problem, this is to be thought of as the need to expand the power of influence of the large masses deprived of the benefits of urban development-expropriated, irregulars, homeless, inhabitants of precarious territories and slums - on the decision-making processes about issues that concern the city as a whole: budget definition; application of public investments in housing, mobility, sanitation; delimitation of priorities; retention of urban surplus value; control of the social function of property; to name just a few.

\section{Social struggles for urban reform and political participation}

In the context of redemocratization of the Brazilian State, the struggles for Urban Reform have resulted in the assimilation, by the State and the legal system, of demands of the popular classes historically allocated in the urban peripheries (Rolnik, 2017, pp. 239-66). The joint mobilization of these actors and others sectors of civil society articulated in networks and collective movements such as the National Forum for Urban Reform [Fórum Nacional pela Reforma Urbana - FNRU] and the National Confederation of Residents' Associations
[Confederação Nacional das Associações de Moradores - Conam] was responsible for making the alarming living conditions in the periphery a matter of "public interest".

Political participation was fundamental for a specific section of Urban Policy, the fruit of a Popular Amendment, to be included in the 1988 Brazilian Federal Constitution, as well for the City Statute (Law 10.257/01) to be approved thirteen years later, which regulated the aforementioned constitutional chapter (Bonduki, 2017; Alfonsin, 2017). These legal devices were responsible for consolidating the aforementioned new conceptual paradigm of urban policy in the Brazilian legal and urbanistic order, which is guided by the social function of property and city and by the political participation in the urban policy decision-making processes, which were both old demands of social movements (Fernandes, 2005).

The agenda of intensifying social participation in urban policy, defended by sectors linked to Urban Reform since the 1980s and applied in a dispersed manner in local contexts, was thus moved to the center of the political arena during the 13 years of discussion of the project of law that would be approved under the title of City Statute. The approval of this legal device was actually only made possible by the mobilization and constant political pressure of the social movements, such as the aforementioned FNRU, which closely followed and actively contributed to the final drafting of the approved law. During this period, the intense conflict of interests between social sectors linked to the Urban Reform and conservative sectors and those linked to capital - who accused the City Statute of affronting the 
rights of property and of free initiative - was explicit (Avritzer, 2010; Gomes, 2018).

The following participatory instruments were established in the City Statute: public policy councils; conferences; participatory budgeting; popular referendum, plebiscite, and popular initiative for draft legislation; public debates and hearings (Avelino, 2016). In addition, the City Statute prescribes mandatory popular participation, publicity and transparency in the process of elaboration of the municipal master plans, an instrument made mandatory for cities with over 20,000 inhabitants. This fact made the local political conjuncture crucial for the promotion of Urban Reform, as the guarantee of the social function of property through the application of the redistributive instruments established by the City Statute - such as, the Special Zones of Social Interest [Zonas Especiais de Interesse Social - ZEIS] - was conditioned to its forecasting and regulation on the respective municipal master plans (Bonduki, 2017).

The social participation agenda was intensified with the election of Lula, the Workers' Party [Partido dos Trabalhadores PT] candidate, to the presidency in 2002. After his election, the Ministry of Cities (2003) and the National Council of Cities (2004) - whose activities were closely linked to the National Conference of Cities, as well to regional and municipal conferences - were created (Rolnik, 2009). In parallel, councils on various fields of urban public policies such as housing, sanitation and transport were established in several cities (Avelino, 2016).

Over the years, however, a position of trust of the social movements towards the institutional arenas of participation gradually became one of questioning the concrete possibilities of interfering in decision-making on urban policy by these means. Although the presence in these arenas has not ceased to be considered essential, subjects linked to the social movements began to point out to the absence of an effective space for deliberation within participatory institutions (Pandolfi \& Espírito Santo, 2014; Trindade, 2014). The absence of coordinating bodies in the established participative spaces, resulting in isolation, fragmentation and consequently inefficiency in the deliberations held (Avelino, 2016), and the progressive emptying of the participative arenas, like the City Council, and its co-optation by the Ministry of Cities (Fernandes, 2013) are some of the reasons for this scenario.

PT's increasing distance from a radical power-sharing agenda, exemplified by the handover of the Ministry of Cities ${ }^{3}$ to the hands of conservative parties (Rolnik, 2009) and abandoning popular participation practices in recent programs for financing urban development (Growth Acceleration Program and My House My Life) or in the realization of the mega events (2014 World Cup and 2016 Olympics), are other reasons for the same picture of mistrust (Bonduki, 2017, p. 45; Rolnik, 2017, p. 249). Lacking space for popular participation and being coordinated almost independently by the real estate market guidelines, such policies have negatively impacted Brazilian cities due to the land speculation stimulus and the consequent increase in land prices, the strengthening of socio-spatial segregation and the completion of several evictions and forced removals (cf. Maricato, 2015; Rolnik et al., 2015). 


\section{The approximation between State and Market in the city of São Paulo}

Although it has promoted the expansion of democratic control over State activity, the valorization of the political participation in civil society in recent decades has also stimulated the approximation between Government and the market in the formulation and implementation of urban policy, in what has been called the "perverse confluence" (Trindade, 2014). In this context, entities linked to the market began to assume or interfere in the tasks that should be the responsibility of public authorities (Arantes, 2007, p. 21), articulating the notion of public interest as way of legitimizing the appropriation of the State apparatus for the pursuit of private interests linked to the accumulation of capital.

Such an approximation between the State and market is associated with what has been conventionally called urban entrepreneurialism, a product of neoliberal ideology defined as a urban governance behavior in which alliances between public authorities, civil society organizations and private interest are mobilized to promote or manage the development of cities (Harvey, 2014, pp. 186-192; Rolnik, 2017, p. 242). In this context, the public sphere is mobilized in order to build consensus on the benefits of adopting a business-oriented practice in urban management, stimulating the "growth at any cost" (Arantes, 2000; Vainer, 2000; Ferreira, 2003; Fix, 2007).

In this context, the city is structured as a "growth machine", the ultimate goal of which is to increase the volume of aggregate rent by intensifying land use (Fix, 2007, p. 24), in which real estate developers use a consistent ideological and discursive apparatus and their influence on the public sphere, if not morally questionable subterfuge - such as the high values spent on electoral campaigns (Rolnik, 2017, pp. 64-65) - to interfere in the functioning of the market, and especially in the decision-making on the application of public investments, seeking to obtain differential or monopolistic rent.

In the city of São Paulo, this situation has been most evident since the management of Paulo Maluf (1992-1995). Since this period - characterized by the establishment of neoliberal consensus in the Brazilian society and by the city of São Paulo's insertion in the globalized financial circuits - the "São Paulo growth machine" has been structured in a more accentuated and active way. Since then, there has been a proliferation of discourses from civil society associations aimed at guiding the application of public investments to specific regions (Frúgoli Jr., 2000).

The so-called "global city myth", for example, has been instrumentalized by various actors - real estate investors, contractors, public authorities, the mainstream media - in order to forge a consensus on the irreversibility and supposed benefits of the economic insertion of the city into the global network of financial flows, justifying the channeling of huge sums of public investment to already historically privileged regions, in order to adapt them to the reception of real estate ventures that would receive large corporations of the "advanced tertiary sector", in spite of the budget restrictions and the ever growing number and size of the slums in the city (Ferreira, 2003; Fix, 2007, 2009). 
In this context, there was a boom in high-end real estate ventures and an intense modernization of the so-called southwest quadrant of the city, which included the reurbanization of the region of Faria Lima Avenue and the construction of a spectacular "global city" landscape along the Marginal Pinheiros. Numerous road improvements had already been implemented in the region and adjacent areas since 1985, mobilizing a more than considerable portion of the public budget, which intensified from the 1990s and onwards: the tunnels under the Ibirapuera Park and the Pinheiros River, the Boulevar JK I and II, the extension of Faria Lima Avenue, the avenue along the Água Espraiada stream and, more recently, the Ponte Estaiada ("cable-tayed bridge") (Maricato, 2000, pp. 158-159; Fix, 2009; Rolnik, 2017, p. 63).

The realization of this "package" of road improvements cannot be attributed solely to the need to increase mobility. They also represented "decoys" to private investment, often being responses to direct demands from real estate developers. In the case of the construction of the Água Espraiada Avenue (renamed Jornalista Roberto Marinho), the municipal management went as far as to carry out the forced and violent removal of more than fifty thousand people previously allocated in slums in the region, aiming to "clean up" the land for private initiative and promoting its maximum profitability and real estate valuation (Fix, 2007, 2009).

The development of the region was stimulated by two Urban Operations [Operações Urbanas] - Água Espraiada and Nova Faria Lima - i.e. an instrument through which the improvement of the urban infrastructure of a given perimeter is funded by the State with the sale of additional construction potential for ventures to be constructed in the perimeter of the operation itself, or, in other words, by the relaxation of land use regulation in a certain "strategic" area.

Advertised as "magic formulae" to enable urban improvements in a context of budget restriction, Urban Operations have proved to be true mechanisms of private appropriation of public resources (Fix, 2004). With their application being viable only in areas of high potential for real estate valuation, and being mandatory that the resources obtained be reinvested in the perimeter of the operation, these instruments have drained a large part of the public budget, promoted a circle of reinvestment in already privileged areas, and restricted the chances of developing precarious in need land, in a clear inversion of the priorities of State urban activity (Massonetto, 2003).

The numerous criticisms directed at Urban Operations by technical and academic sectors led to the reformulation of part of its elements by the time of the approval of the 2014 Strategic Master Plan. The following elements were established in the referred Master Plan: the expanded perimeter - in order to allow the application of the obtained resources in a larger perimeter than that of the Operation, reducing the concentration of investments; the binding of $25 \%$ of the obtained resources for the acquisition and construction of social housing; and the composition of managing boards of the Operations with equal representation from civil society and the State (Bonduki \& Rossetto, 2018, pp. 237-244). 
The same process of approximation between the State and sectors of civil society linked to the market is evident in the current discussions on the requalification of the Historical Center of the city. Since the 1990s, a group articulated around the Viva o Centro Association [Associação Viva o Centro AVC] - an entity composed by the largest real estate owners in the region -, started to defend the need for the requalification of the region in face of its degradation (Frúgoli Jr., 2000; Arantes, 2007). Since then, a series of proposals for the requalification of the Historical Center have been formulated, all centered on attracting private investors to the region through public-private partnerships, aimed to reformulate the urban infrastructure of the territory, such as Operação Urbana Centro, Programa Ação Centro (ProCentro), and its corollary the Projeto Nova Luz ("Nova Luz Project").

In the case of the Nova Luz Project whose implementation has been suspended, but not yet completely dismissed -, the implementation of a second form of publicprivate partnership was proposed, the Urban Concession [Concessão Urbanística], regulated in São Paulo by Law 14.197/2009. Based on this instrument, the execution of urban work in a certain perimeter may be given to a company or joint venture through a bidding process. In return, the concessionaire may commercially exploit the properties and public areas installed in the perimeter, as well as promote expropriations, which until then was an exclusive power of the State (Pallamin, 2015, p. 69).

In this context of approximation between the State and the market, any project aimed at the requalification of the Historical
Center of São Paulo should be conducted on the condition that the interests of the real estate market do not overlap those of the population currently allocated in the area, mostly from the lower classes. The equal and decisive representation of these social sectors in the formulation and implementation of these projects, security against evictions and induced processes of gentrification, and the expansion of popular housing in this territory should be top of the list of priorities for the State in all stages of this possible intervention.

\section{Clashes in São Paulo's public sphere and its impact on law}

The fact that entities linked to the market have exerted a strong influence on public opinion and on São Paulo's urban public policies in recent years does not mean the absence of conflict or contestation by other sectors of civil society. Acts of resistance to the commercialization of urban land make the city of São Paulo an arena of intense political dispute and confrontation by groups with interests which are irreconcilable with those of the market. The processes of elaboration of the Strategic Master Plans of 2002 and 2014 have shown the existence of a multiplicity of divergent interests and expectations about the development of the city of São Paulo.

The São Paulo's Master Plan of 2002, one of the first to be approved after the City Statute came into effect, was preceded by a broad participatory process, consisting of 26 public hearings and numerous specific meetings with diverse social actors. Among the more than 230 organizations that participated in the process, 
the negotiation was fundamentally influenced by the participation of three collective organizations, namely, the Front for Citizenship [Frente pela Cidadania], which represented the estate sector, led by Secovi; the Popular Front for the Master Plan [Frente Popular pelo Plano Diretor], composed of housing movements, NGOs and urban planners linked to the FNRU, whose main demand was the regulation, the self-applicability and the expansion in number of the Special Zones of Social Interest; and the Defend São Paulo [Defenda São Paulo], which aggregated middle class residents associations and whose concern was the maintenance of the zoning rules, especially regarding the exclusive residential areas (Bonduki and Rossetto, 2018, pp. 193-202).

While the demands of the last two groups were negotiated without major obstacles, the pressure exerted by the real estate sector through the Front for Citizenship made the approval of the Master Plan quite complex. The real estate sector relied on its influence in the public sphere, promoting a broad advertising campaign that criticized the bill presented, in order to assert its interests, especially regarding the no-limitation of the right to build. However, after a broad negotiation a restriction to the interests of the real estate sector was established, in order to benefit the community, with the fixation of the thesis that the right to build is not a direct consequence of the right to property, but it must be linked to the urban development strategy established by the Master Plan. The State has established a charge for those who wish to reach the maximum usage coefficient established by the zoning law.

For the elaboration of the 2014 Master Plan, the participatory process carried out in 2002 was not only reproduced, but it was substantially expanded and improved. The nine months of processing of the 2014 Master Plan Bill were characterized by a deep concern with disclosure, transparency, negotiation and incorporation of proposal and demands. In consequence, the approved text was substantially different and much more comprehensive than the one initially presented. During the period 65 public hearing were held, besides a wide dissemination through multiple media, stimulating the engagement and participation of civil society (Bonduki and Rossetto, 2018, pp. 203-213).

The three main collective organization that participated in the elaboration of the 2002 Master Plan were present in 2014, but a new range of interlocutors also played a significant role in the process. The Movement of Roofless Workers [Movimento dos Trabalhadores Sem-Teto - MTST] played a crucial role not only in the conquest of new Special Zones of Social Interest in areas recently occupied by its militants, but also because of the intense pressure exerted for the approval of the Master Plan after its demands were met, including by the installation of a camp - along with other housing movements - in front of the City Council in the final 10 days of discussion of the bill. Besides, the participation of independent collectives was fundamental for the incorporation into the 2014 Master Plan of topics and issues related to the alteration of the hegemonic model of development of the city, especially regarding the use public space, the active mobility, the urban agriculture and the cultural heritage.

It can be concluded that the existence of a broad process of negotiation and political participation in the processes of elaboration 
of the 2002 and the 2014 São Paulo's Master Plans made it possible for consensus to be obtained and crystalized into a legal device with democratic legitimacy. In spite of that, the political dispute over the Right to the City does not end with the establishment of a static legal arrangement. On the contrary, it is based on a constant struggle for the effectiveness and the collective elaboration of the conditions for the application of the law, through continuous and dynamic political participation. This means that achieving consensus in the form of law is only an initial step in the process, which continues in the public sphere through the dispute for effectiveness and interpretation of the law. This stage is characterized by dissent, i.e. the confrontation of diverging opinions, which contributes to the development of the law over time. To conclude this section, we will try to demonstrate that the clashes in the public sphere operate reinterpretations of the principle of the social function of property and city, guaranteed by the Brazilian Federal Constitution and the City Statute, but devoid of predefined meaning and condition of application.

Currently, various forms of protests are articulated in the city of São Paulo by those who understand that the institutional spaces of deliberation are not capable of absorbing their demands, as well as not stimulating real transformations in urban public policies. In this context, forms of direct actions are carried out especially through social mobilization and coordinated activities, seeking to bring visibility to issues and points of views often neglected or openly rejected by the traditional spaces of deliberation and shaping of public opinion, historically monopolized by the dominant classes.
An important example of this type of action is the occupation of idle properties by groups involved in housing struggles, especially in the central region of the city, claimed as the proper place for the construction of popular housing, given its complete urban infrastructure and the proximity to the labor market. Through their occupations, the social movements have brought visibility to one of the main contradictions of urban development in São Paulo: the restricted access to land, its concentration in the hands of a few, and the exclusionary character of the housing market, resulting in a deep housing deficit, and the speculative retention of idle property by landowners who expect to obtain future rents (Boulos, 2018).

This practice has been a central and systematic strategy for these movements since 1997 , as a way of putting political pressure on the competent authorities, bringing visibility to the decent housing agenda and demanding that the State create channels of dialogue and negotiation (Trindade, 2014). By directing their occupations to the central region of the city, where the largest number of idle properties is concentrated, the housing movements have become important actors in the debate on public policies for the central region of São Paulo, as well as the main opponents to the aforementioned projects of requalification of the area (Trindade, 2014, p. 134).

The occupation of idle property is in a rather ambiguous position, socially as well as legally. On the one hand, it constitutes an afront to the legal order, especially regarding the right to property, which is why it is strongly criticized by public opinion and suppressed by the State through repossession lawsuits. 
The precarious living conditions to which the occupants are submitted, putting their health and safety at risk, generate divergences even within the social movements for housing, regarding the validity of occupation as a temporary place of housing (Trindade, 2014, pp. 156-158). This precarious situation was exposed by the fire and collapse of the Wilton Paes de Almeida Building in May of 2018 and presents itself as one of the most sensitive points of discussion about the occupation of idle properties.

The ambiguity lies in the fact that the occupation of idle properties, while affronting the established legal order with regards to property rights, are at the same time a demand for effectiveness of the very legal order in question, which guarantees the right to decent housing and requires that private property fulfil its social function (Trindade, 2014, pp. 183-184; Boulos, 2018). This guarantee must be enforced by the State by inspecting land use, the application of the instruments of compulsory land use, occupation and subdivision, of the taxation on urban property progressive in time, and the expropriation of idle properties. ${ }^{4}$ Established by the City Statue, the effectiveness of these instruments is still low in limiting the speculative retention of underused property (cf. Bonduki \& Rossetto, 2018, pp. 216-222).

From another point of view, despite the precarious living conditions inside the occupied buildings, they are understood by most occupants as the only viable way for obtaining a roof over their heads, even if temporary, given the exclusionary conditions of the housing market (Boulos, 2018). It is therefore essential to discuss the State's responsibility for providing the minimum safety conditions to the residents of occupied buildings, despite the irregular nature of the land tenure.

While considering their ambiguous character, at the same time legitimate and illegitimate, it should be recognized that the occupations present themselves as a collective reaction to an excluding urban development and to the evident lack of effectiveness of social rights and redistributive instruments guaranteed in the legal system, especially in the Brazilian Federal Constitution and the City Statute (Boulos, 2018). By exposing their demands, the social movements encourage a debate on the status of individual property as an unrestricted right, pointing to the need for effective legal instruments to ensure that its social function is fulfilled (Trindade, 2014, p. 164). This tension in the discursive field is, even if in a discontinuous and unpredictable manner, assimilated by the legal conscience and by the State and its judicial authorities. By these means, the very content of the social function of property is progressively updated.

Other communities, in turn, have contributed to the construction of the sense of a principle whose indetermination is even deeper, which is the principle of the social function of the city. The so-called "new urban activism" (Frúgoli Jr., 2018) is composed by associations and groups of people, in most cases organized horizontally and informally, that demand a reformulation of certain aspects of daily life in the city. The proliferation of these groups occur at a time of greater complexity and heterogeneity in the public sphere of São Paulo, as documented by Caldeira (2012, 2014a, 2014b), resulting from the years of economic growth, the relative reduction of socioeconomic inequalities, and 
the inclusion of the working classes by the means of consumption in the first decade of the 21st century (cf. Marques, 2014).

According to Valluchi (2017), the new urban activism, in short, propagate movements of commoning, the act or practice of creating a common good. In Harvey's words (2014, p. 145), commoning is a form of relationship between a social group and a good or aspect of the environment, in which its use and appropriation takes place in a collective and not commercial manner. The public goods and spaces found in the city are therefore not necessarily "common" but become so when society appropriate them for a collective purpose and for its equitable enjoyment by the population in general. Making the city and the resources it provides a common good, accessible and manageable by all, is the principle that at first sight guides the action of these activists.

Some of these groups demand substantial changes in the current use of urban public spaces (Frúgoli Jr., 2018). In the center and the periphery of the city, it is demanded and at the same time put into practice the definitive or punctual transformation of public roads into parks and leisure spaces (Haddad, 2019); the use of public space for culture such as parties, festivals, audiovisual exhibitions, artistic performances and debates (Almeida, 2013; Aderaldo, 2016; Verano, 2018); the shared management of public spaces and the promotion of urban agroecology and community gardens (Machini, 2018).

Better public transportation, containing fare increase and its primacy over the individual automobile are also demanded by collectives such as the Free Pass Movement [Movimento Passe Livre - MPL], whose protests were the fuse for the so-called 2013 Journeys of June [Jornadas de Junho de 2013] (cf. Maricato et al., 2013). At the core of their demand is the view that free movement around the city is a sine qua non condition for the collective enjoyment by the citizens.

Uniting contestation and creativity, urban activists demand the maximization of the city as value of use, that is, as an arena for the autonomous elaboration of collective needs and of the social ways of satisfying them in urban space (Lefebvre, 2008). While they reject unilateral views of public space as a mere place of passage and circulation of goods and people, they emphasize the possibility of permanence and simultaneity; they value the city as a meeting place, a place of the unexpected, a place of play and exchange (ibid., p. 105).

They seek a public space characterized by "indeterminacy" of uses and people who pass through it, where the legitimate and the illegitimate are not defined a priori but result from deliberation and social participation. Such space is associated with the very concept of the democratic public sphere, that in which in the absence of a foundation, the meaning and unity of the social is negotiated - at once constituted and put at risk (Deutsche, 2018, pp. 120-121).

With this objective in mind, these groups are not restricted to demanding the possibility of access to a pre-existing public space but are seeking ways to exercise the right to build collectively and progressively an imagined and more democratic public space, seen and appropriated in the form of a "common". Therefore, there is a need for actions of coordinated resistance to the processes of appropriation of public space by 
the commercial and privatizing logic, which multiply under the aegis of neoliberalism (Harvey, 2014, pp. 164-169).

It is known that in São Paulo, as in Brazilian cities in general, there has never been a public space appropriated as a "common". Due to an exclusionary urban development as well as other material, political and social conditions characteristic of a stratified and unequal society, the access to the city as a whole and its public spaces have historically been denied to the vast majority of the population continuously expelled to peripheries increasingly distant of the center of the city, endowed with infrastructure, services and places for culture, leisure and consumption (cf. Caldeira, 2011; Rolnik, 2017).

More recently, São Paulo has been structured as a "city of walls" by the dissemination of secure private spaces that directly deny public space and public life (Caldeira, 2011). Currently these fortified enclaves have taken the form of megaprojects that mix residential, consumption and business functions, constituting giant antiurban machines (Fix, 2009, p. 42). Therefore, the public space cannot be understood as something that has been lost and needs to be recovered, but rather as something that needs to be created by political activity.

These movements and communities that are currently reconfiguring the public sphere of São Paulo, not limited to those who call themselves activists but involving all those who articulate new ways of relating to the city, seek the realization of basic principles and rights: the possibility to circulate, stay and intervene in urban spaces; to consume the products available on the market; to express themselves by culture and symbols and to formulate their own identities and, finally, the right to moral and civic recognition of those who have historically been excluded, silenced and targeted by the most cruel forms of violence (Caldeira, 2011, 2012, 2014a, 2014b; Pallamin, 2015).

These activities make the public sphere of São Paulo extremely pulsating and dissenting, so that new meanings and interpretations are attributed to the principle of the social function of the city. The city must be constantly transformed in order to accommodate its multiple functions in an equal manner, in order to satisfy the diverse social needs of urban populations. As new political subjects formulate new needs and assign new uses to urban spaces, the very concept of the social function of the city is expanded, absorbing these updates from social practices. As a result of social mobilization, the city will hold as many functions as are imagined for it.

\section{Final considerations}

As shown, since the period of redemocratization of the Brazilian State, political participation has been decisive for the renewal of the urban-legal order in favor of an egalitarian and democratic urban development. However, this period also featured evident discontinuities - the emptying and weakening of institutional spaces for political deliberation - and contradictions - the penetration of neoliberal ideology and urban entrepreneurship strategies in the Brazilian context. Recently, 
new forms of enunciation outside the institutional spaces of participation have expanded the discursive field, exposing the contradictions in the process of urbanization and demanding in a renewed way deep transformations to the current exclusionary structures that shape the urban space and restrict its functions and uses.

It was sought to demonstrate that a proper understanding of the Right to the City, even from a perspective that considers its legal aspects, requires looking outside the Law, towards social and political practices. There is a permanent and insoluble contradiction between the existing Law, its current interpretation and forms of application, and the social practices, which continually articulate and demand new senses and a new perspective for legal institutions, in favor of the democratization of social relations and the equal enjoyment of constitutional and infra-constitutional rights and guarantees. As a result of this tension, arising from political participation, the Law is progressively renewed and updated.

As a general idea, the Right to the City is understood as the collective power of the population to modify the way in which the process of urbanization has historically taken place, resulting in exclusions, massive expropriations, and alienation. In the course of history, the Right to the City has presented itself as a counterpoint to structural elements of the exclusionary urbanization that has taken place on a global scale until the present day, elements which are currently stimulated by neoliberal ideology and globalization: unequal land development, socio-spatial segregation, commercialization of social relations, privatization of existence, excessive verticalization and highway culture, environmental pollution and devastation, endemic violence, and denial of social rights or, what in some cases is equivalent, denial of the very means of living.

From this general concept, the Right to the City takes on particular forms in local contexts, as a result of the multiple appropriations and interpretations given to it in different social contexts, especially by popular movements. In each situation, specific categories are elaborated, bringing concreteness and directing the social struggle in one direction or another.

In the Brazilian case, the dynamic process of exercising the Right to the City by the population is strongly mediated by the principles of the social function of property and city and of the democratic management of the city, which, together and in their mutual implication, are the foundations of a new conceptual paradigm on urban public policy. These categories are the result of the social struggles, formulated and defended by the popular movements themselves and later included in State law and welcomed by legal conscience. The current disputes over the Right to the City in Brazil can, in simple terms, be understood as demands for the effectiveness of these principles and the urban-legal order that they support.

These demands are articulated within the public sphere by the clash of values, worldviews, and political projects, responsible for the reformulation of the conditions of State activity's legitimacy and for attributing new meanings to existing Law. The Right to the City is therefore associated with the 
construction of an active and heterogeneous public sphere - or public spheres -, capable of establishing the conflict between multiple positions and shared values, establishing dissent as an instrument for the constant renewal of social reproduction practices.
This process will only take place through the horizontal and vertical democratization of society, that is, through the reduction of internal inequalities within society and the increasing capture of the population's demands by the State.

\section{[I] https://orcid.org/0000-0003-0785-9427}

Autonomous researcher. São Paulo, SP/Brazil. arthur.prist@hotmail.com

\section{[II] https://orcid.org/0000-0003-2862-8986}

University of São Paulo, Law School, State Law Department. São Paulo, SP/Brazil. mariapaula@usp.br

Translation: this article was translated from Portuguese to English by the author.

\section{Notes}

(1) All quotations are originally in Portuguese, even those of foreign authors, whose quotations were extracted from translated versions of their works. In this English version, all quotations have been freely translated by the authors, and are their sole responsibility.

(2) The concept of public sphere was initially formulated by Jürgen Habermas in his work "The Structural Transformation of the Public Sphere: An Inquiry into a Category of Bourgeois Society" (2014, São Paulo, Ed. Unesp), originally published in 1962. The concept was later appropriated by several authors, who presented a critical position towards Habermas' work, which led to a progressive renewal of the concept (Avritzer \& Costa, 2004). In 1992, in his work "Between Facts and Norms: Contributions to a Discourse Theory of Law and Democracy" (1997), Habermas presented a quite modified version of the concept, linking it to his theory of discourse and of the democratic proceduralism. This article is based on this last version of the concept outlined by Habermas, as well as on critical receptions made by other authors.

(3) The Ministry of Cities was later cut in the first year of Jair Bolsonaro's government, and merged with the also cut Ministry of National Integration becoming the Ministry of Regional Development. 
(4) The compulsory land use, occupation and subdivision, the taxes on urban property (IPTU) progressive in time, and the expropriation of idle properties were established by the City Statute, in its sections II to IV, as instruments to be applied in sequence. Once the existence of unbuilt, underused or unused urban land has been established, the obligation and the time limit for its compulsory subdivision, building or use must be fixed. If the landowner fails to comply with this obligation within the prescribed period, the Municipality must apply the progressive tax over time, increasing the rate charged for a period of five consecutive years. Finally, after the five years of application of the progressive tax over urban property without the fulfillment of the obligation by the landowner, the Municipality must promote the expropriation of the underutilized property. The application of these instruments is responsibility of the Municipality and depends on its prevision and regulation in the municipal Master Plan. The local political mobilization for its effectiveness is therefore crucial.

\section{References}

ADERALDO, G. A. (2016). “Entre imagens e imaginários: estética e política nas intervenções visuais/ audiovisuais de coletivos culturais paulistanos". In: KOWARICK, L.; FRÚGOLI JR., H. (orgs.). Pluralidade urbana em São Paulo: vulnerabilidade, marginalidade, ativismos. São Paulo, Editora 34, Fapesp.

ALFONSIN, B. M. et al. (2017). Das ruas de Paris a Quito: o direito à cidade na Nova Agenda Urbana HABITAT III. Revista de Direito da Cidade. Rio de Janeiro, v. 9, n. 3, pp. 1214-1246.

ALMEIDA, R. S. (2013). Juventude, direito à cidade e cidadania cultural na periferia de São Paulo. Revista do Instituto de Estudos Brasileiros. São Paulo, n. 56, pp. 151-172.

ARANTES, O. (2000). "Uma estratégia fatal: a cultura nas novas gestões urbanas". In: ARANTES, O.; VAINER, C.; MARICATO, E. (orgs.). A cidade do pensamento único - desmanchando consensos. Petrópolis, Vozes.

ARANTES, P. (2007). Interesse público, poderes privados e práticas discursivas na política de renovação do Centro de São Paulo. São Paulo, Instituto Polis.

AVELINO, D. P. (2016). "Cidade e cidadania: considerações sobre a gestão democrática na política urbana brasileira". In: COSTA, M. A. (org.). O Estatuto da Cidade e a Habitat III: um balanço de quinze anos de política urbana no Brasil e a nova agenda urbana. Brasília, Ipea.

AVRITZER, L. (2010). O Estatuto da Cidade e a democratização das políticas urbanas no Brasil. Revista Crítica de Ciências Sociais. Coimbra, v. 91, pp. 205-221.

AVRITZER, L.; COSTA, S. (2004). Teoria crítica, democracia e esfera pública: concepções e usos na América Latina. DADOS - Revista de Ciências Sociais. Rio de Janeiro, v. 47, n. 4, pp. 703-728.

BONDUKI, N. (2017). Política urbana e a reforma do Estado: da redemocratização aos novos desafios do século XXI. Revista Simetria. São Paulo, v. 3, pp. 41-52. 
BONDUKI, N.; ROSSETTO, R. (2018). “A reforma urbana no Plano Diretor Estratégico de São Paulo de 2002 a 2014". In: BONDUKI, N. (org.). A luta pela reforma urbana no Brasil: do seminário de Habitação e Reforma Urbana ao Plano Diretor de São Paulo. São Paulo, Instituto Casa da Cidade.

BOULOS, G. (2018). Por que ocupamos? Uma introdução à luta dos sem-teto. São Paulo, Autonomia Literária.

CALDEIRA, T. P. do R. (2014a). Gênero continua a ser o campo de batalhas: juventude, produção cultural e a reinvenção do espaço público em São Paulo. Revista USP. São Paulo, n. 102, pp. 83-100.

(2014b). Qual a novidade dos rolezinhos? Espaço público, desigualdade e mudança em São Paulo. Novos Estudos - Cebrap [online], n. 98, pp. 13-20.

(2012). Inscrição e Circulação: Novas visibilidades e configurações do espaço público em São Paulo. Novos Estudos - Cebrap [online], n. 94, pp. 31-67.

(2011). Cidade de Muros. São Paulo, Editora 34, Edusp.

DEUTSCHE, R. (2018). Agorafobia. Arte e Ensaios - UFRJ. Rio de Janeiro, n. 36, pp. 116-173.

FERNANDES, E. (2013). Estatuto da Cidade, mais de 10 ano depois: razão de descrença, ou razão de otimismo? Revista UFMG. Belo Horizonte, v. 20, n. 1, pp. 212-233.

(2005). Direito e gestão na construção da cidade democrática no Brasil. Oculum Ensaios. Campinas, n. 4, pp. 16-33.

FIX, M. (2004). “A "fórmula mágica" da parceria público-privada: operações urbanas em São Paulo" In: SCHICCHI, M. C.; BENFATTI, D. (orgs.). Urbanismo: dossiê São Paulo - Rio de Janeiro. Campinas, Puccamp/Prourb.

(2007). São Paulo cidade global: fundamentos financeiros de uma miragem. São Paulo, Boitempo.

(2009). Uma ponte para a especulação: a arte da renda na montagem de uma "cidade global". Cadernos CRH. Salvador, v. 22, n. 55, pp. 41-64.

FRASER, N. (1992) Rethinking the Public Sphere: A contribution to the Critique of Actually Existing Democracy. Social Text, n. 25/26, pp. 56-80.

FRÚGOLI JR., H. (2018) Ativismos urbanos em São Paulo. Caderno CRH. Salvador, v. 31, n. 82, pp. 75-86. (2000). Centralidade em São Paulo: trajetórias, conflitos e negociações na metrópole. São Paulo, Editora da Universidade de São Paulo.

GOMES, A. M. I. dos S. (2018). O direito à cidade sob uma perspectiva jurídico-sociológica. Revista Direito GV [online], v. 14, n. 2, pp. 492-512.

HABERMAS, J. (1997). Direito e democracia: entre facticidade e validade, v. II. Rio de Janeiro, Tempo Brasileiro.

HADDAD, F. (2019). Função Social das Vias Urbanas: uma análise à luz da teoria jurídica das políticas públicas. Dissertação de mestrado. São Paulo, Universidade de São Paulo.

HARVEY, D. (2014). Cidades rebeldes: do direito à cidade à revolução urbana. São Paulo, Martins Fontes.

LEFEBVRE, H. (2008). O direito à cidade. São Paulo, Centauro. 
MACHADO, M. R. A.; MELO, R.; SILVA, F. G. (2010). A esfera pública e as proteções legais anti-racismo no Brasil. Cadernos de Filosofia Alemã. São Paulo, n. 16, pp. 95-116.

MACHINI, M. (2018). "Fluxos e sentidos da cidade-em-cultivo". In: MAGNANI, J. C.; SPAGGIARI, E. (orgs.). Lazer de perto e de dentro: uma abordagem antropológica. São Paulo, Ed. Sesc.

MARICATO, E. (2000) "As ideias fora do lugar e o lugar fora das ideias". In: ARANTES, O.; VAINER, C.; MARICATO, E. A cidade do pensamento único - desmanchando consensos. Petrópolis, Vozes.

(2015a). “Globalização e política urbana na periferia do capitalismo". In: MARICATO, E. Para entender a crise urbana. São Paulo, Expressão Popular.

(2015b). "Cidades e luta de classes no Brasil”. In: MARICATO, E. Para entender a crise urbana. São Paulo, Expressão Popular.

MARICATO, E. et al. (2013). Cidades rebeldes: Passe livre e as manifestações que tomaram as ruas do Brasil. São Paulo, Boitempo, Carta Maior.

MARQUES, E. (2014). A metrópole de São Paulo no início do século XXI. Revista USP. São Paulo, n. 102, pp. 23-32.

MASSONETTO, L. F. (2003). Operações Urbanas Consorciadas: a nova regulação urbana em questão. Revista da Procuradoria-Geral do Município de Porto Alegre. Porto Alegre, n. 17, pp. 101-118.

MELO, R. (2015). Repensando a esfera pública: esboço de uma teoria crítica da democracia. Lua Nova: Revista de Cultura e Política [online], v. 1, n. 94, pp. 11-39.

PALLAMIN, V. (2015). Arte, Cultura e Cidade. São Paulo, Annablume.

PANDOLFI, D.; ESPÍRITO SANTO, W. R. do (2014). "Movimentos sociais urbanos e esfera pública: questões para o debate". In: LOPES, J. S. L.; HEREDIA, M. A. de (orgs.). Movimentos sociais e esfera pública: o mundo da participação: burocracias, confrontos, aprendizados inesperados. Rio de Janeiro, CBAE.

PERLATTO, F. (2015). Seletividade da esfera pública e esferas públicas subalternas: disputas e possibilidades na modernização brasileira. Revista de Sociologia e Política - UFPR. Curitiba, v. 23, n. 53, pp. 121-145.

ROLNIK, R. (2009). Democracia no fio da navalha: limites e possibilidades para a implementação de uma agenda de Reforma Urbana no Brasil. Revista Brasileira de Estudos Urbanos e Regionais [online], v. 11, n. 2, pp. 31-50.

(2017). Territórios em conflito: São Paulo: espaço, história e política. São Paulo, Três Estrelas.

ROLNIK, R. et al. (2015). O Programa Minha Casa Minha Vida nas regiões metropolitanas de São Paulo e Campinas: aspectos socioespaciais e segregação. Cadernos Metrópole. São Paulo, v. 17, n. 33, pp. 127-154.

TAVOLARI, B. (2016). Direito à cidade: uma trajetória conceitual. Novos Estudos - Cebrap [online], v. 35, n. 1, pp. 93-109.

TRINDADE, T. A. (2014). Ampliando o debate sobre a participação política e a construção democrática: o movimento de moradia e as ocupações de imóveis ociosos no centro da cidade de São Paulo. Tese de doutorado. Campinas, Universidade Estadual de Campinas. 
VAINER, C. (2000). "Pátria, empresa e mercadoria". In: ARANTES, O.; VAINER, C.; MARICATO, E. A cidade do pensamento único - desmanchando consensos. Petrópolis, Vozes.

VALLUCHI, L. V. B. (2017). São Paulo, da cidade de muros à cidade ocupada: insurgências e contradições. In: XVII ENCONTRO NACIONAL DA ASSOCIAÇÂO NACIONAL DE PÓS-GRADUAÇÃO E PESQUISA EM PLANEJAMENTO URBANO E REGIONAL. Anais... São Paulo.

VERANO, P. N. (2018). Cidades temporárias: brechas e contrabrechas na cidade. Tese de doutorado. São Paulo, Universidade de São Paulo.

Received: August 11, 2020

Approved: December 7, 2020 